\title{
DYNAMICS OF COCCIDIAL INFECTION IN FREE LIVING AND CAGE-REARED EUROPEAN HARES
}

\author{
K. CHROUST \\ State Veterinary Institute, 46311 Vratislavice n. Nisou
}

Received December 1, 1983

\begin{abstract}
Chroust K.: Dynamics of Coccidial Infection in Free Living and Cage-reared European Hares. Acta vet. Brno, 53, 1984: 175-182.

Examinations for coccidia in free living and cage-reared hares were carried out during the years 1977 to 1982 and 1980 to 1982, respectively. Examinations were made of a total of 364 faecal samples collected from decayed hares found in the wild, 629 samples collected in natural habitats of hares, and 1301 samples collected from cage-reared hares. Faecal examinations were both quantitative and qualitative, i. e. the average numbers of coccidial oocysts shed per gram of faeces (OPG) and the proportions of the individual coccidial species were determined.

The results show the dynamic pattern of the coccidial oocyst shedding during the year with a maximum in late summer and autumn (August to October) followed by a second maximum in March and April. Minimum numbers were shed in June and July. The pattern of oocyst excretion was similar in free living and cage-reared hares. However, higher OPG numbers were found in the cage-reared animals.

Among the coccidial species found in our material mostly $E$. leporis and E. robertsoni were encountered, representing 65 to 76 per cent of all oocysts shed. Further, quantitatively more important species were: $E$. europaea, $E$. hungarica, E. semisculpta, E. septentrionalis and $E$. townsendi. The pattern for the individual coccidial species shed was not subject to major changes during the year.

The results provide a basis for selection and administration of suitable coccidiostats for cage-reared hares in periods of high risk, and for measures aimed at protection of wild hare population.
\end{abstract}

European hare (Lepus eropaeus P.), coccidial infection, losses, shedding pattern.

Coccidia are among the most potent pathogenic parasites of hares. Coccidial infections had even become a limiting factor in experiments the goal of which was artificial rearing of hares (Kučera 1983). A similar situation prevails under natural conditions where coccidia combined with lung and digestive tract nematodes have quite literally become a major population regulatory factor of the hare population. A detailed analysis based on necropsy and laboratory examinations of 6341 hares from throughout the Czech Socialist Republic during the years 1967-1981 (Šterr ba 1982, 1983) showed that parasitic infestations resulted in a mortality rate of 22.8 per cent of the specimens submitted, with coccidiosis constituting 62.3 per cent of these losses. The highest losses due to coccidiosis have been most frequently diagnosed in October and November and again in March and April. Parasitism as the cause of death was determined in 18 per cent of hares examined from 1970 to 1975 in Austria (Kutzer 1976) also with highest losses reported in autumn. Coccidia were identified in 90 per cent of the 900 examined samples. Coccidiosis was the cause of death in 90 per cent of animals in the one year period when the ,monodiets" were fed to hares (Kučera 1979). In a south Moravia study coccidia were detected in 92 per cent of examined dead hares (Novák 1966).

The importance of coccidiosis in hares has been recognized in several countries: in Hungary (Pellérdy 1956), in Poland (Pastuszko 1961), in GDR (Gräfner et al. 1967; Ha upt and Hartung 1977), in GFR (Brüll 1972, 1979; Barth and Brüll 1975; Starke 1976).

These studies indicate that the presence of coccidia should be considered as a part of a complex 
of parasitic fauna in hares. Nevertheless, the high pathogenity of coccidia and their deleterious effect on the course of other concomitant diseases require that they be given special attention for the effective production management and disease prevention in hares.

We therefore investigated in some detail occurrence, dynamics of infection and species participation of coccidia in these infections. We further compared findings obtained from wild hares with those in cage-reared animals. Our investigation was aimed at better health control in both wild and artificially reared hares.

\section{Materials and Methods}

Our field study consisted of a detailed gross pathological and laboratory examination of the remains of free living hares, faecal examination of wild hares obtained by hunting and examination of hare faeces collected at selected locations of natural hare habitats throughout the year. This examination for evidence of coccidiosis was carried out for a 6 year period (1977 to 1982) and a total of 364 samples of faeces from decayed hares and 629 samples obtained from shot animals were evaluated. Our study covered various geographical regions of the C.S.R.: a lowland region (South Moravia, the districts Břeclav, Brno-venkov, Brno-město and Hodonín), a karst-land region (the Blansko district) and a highland region (Ždár n. Sázavou), as well as a mountainous and submontane regions (the districts of Šumperk and Ústí n. Orlicí).

Further, a systematic study of coccidial occurrence and infection dynamics was performed on two farms with cage rearing of hares. In these investigations a total of 1301 samples of faeces were examined. The numbers of faecal samples for each category of animals are given in Tables 1 and 2 .

The examinations were carried out on a quantitative basis, i. e. mean numbers of oocysts were determined per $1 \mathrm{~g}$ of faeces (OPG). A modified Gordon-Whitlock method using the McMaster counting chamber was employed (Chroust 1970). The individual coccidial species were determined in the samples according to the key employed in the work of Chroust (1978).

\section{Results}

Detailed information on the numbers of faecal samples examined and quantitative data on oocyst findings according to both month of collection and free living or cage-reared hares are given in Table 1 . Sample numbers were evenly distributed

Table 1

Numbers of hare faecal samples collected in the years 1977 to 1982

\begin{tabular}{|l|r|r|r|r|r|r|r|}
\hline \multicolumn{1}{|c|}{ Samples collected } & 1977 & 1978 & 1979 & 1980 & 1981 & 1982 & Total \\
\hline $\begin{array}{l}\text { From decayed wild } \\
\text { hares }\end{array}$ & 82 & 24 & 70 & 62 & 44 & 82 & 364 \\
$\begin{array}{l}\text { From natural hare } \\
\text { habitats }\end{array}$ & 96 & 122 & 132 & 104 & 108 & 67 & 629 \\
$\begin{array}{l}\text { From cage reared } \\
\text { hares }\end{array}$ & 0 & 0 & 0 & 614 & 363 & 324 & 1301 \\
\hline
\end{tabular}

throughout the year during the experimental periods, which covered the years 1977 to 1982 in wild hares and 1980 to 1982 in the cage-reared ones. The pattern of oocyst shedding is given in Fig. 1-3. Quantitative findings for oocyst numbers in decayed hares during the year reached roughly 6000 to 54000 OPG, in field-collected samples 6500 to 29000 OPG, and in cage-reared hares from 14000 to more than 100000 OPG (Table 2). The number of oocysts excreted during the course of the year was very much uniform for all three groups of animals, with the only differences appearing in the mean number of OPG in faecal samples. Maximum numbers were in the autumn months of September and October in free li- 


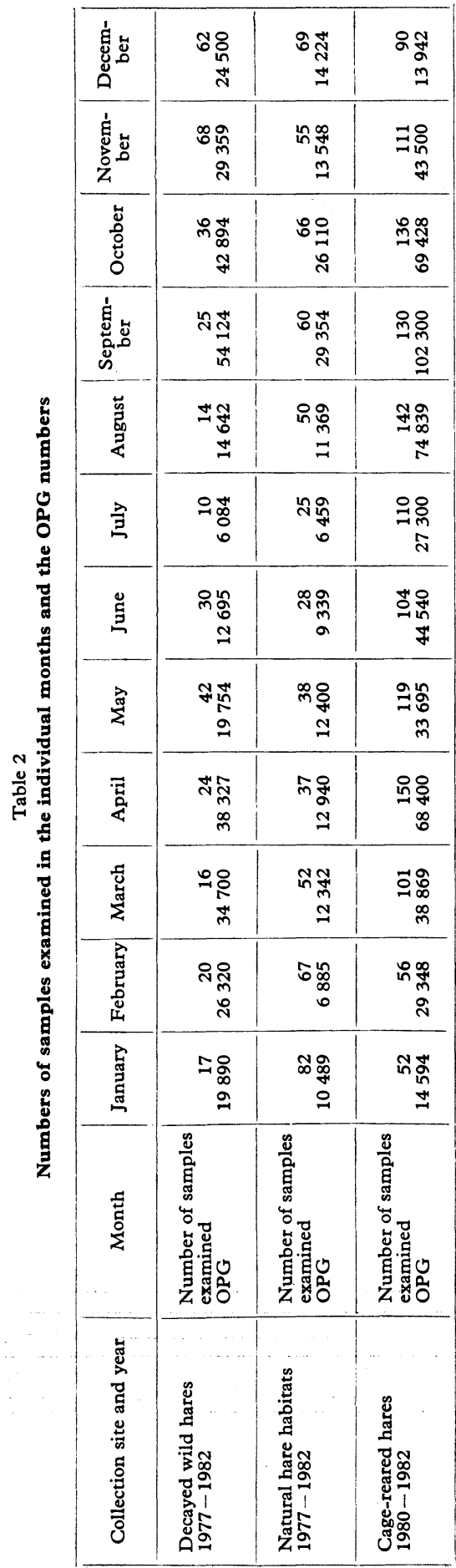




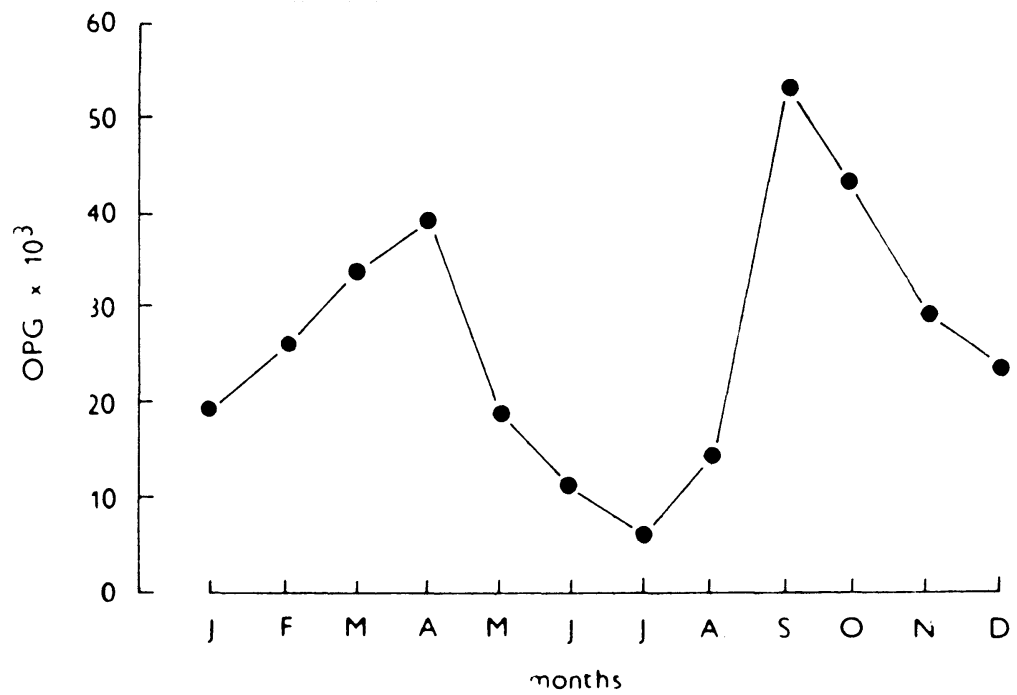

Fig. 1. Coccidial infestation curve in decayed free living hares during the year.

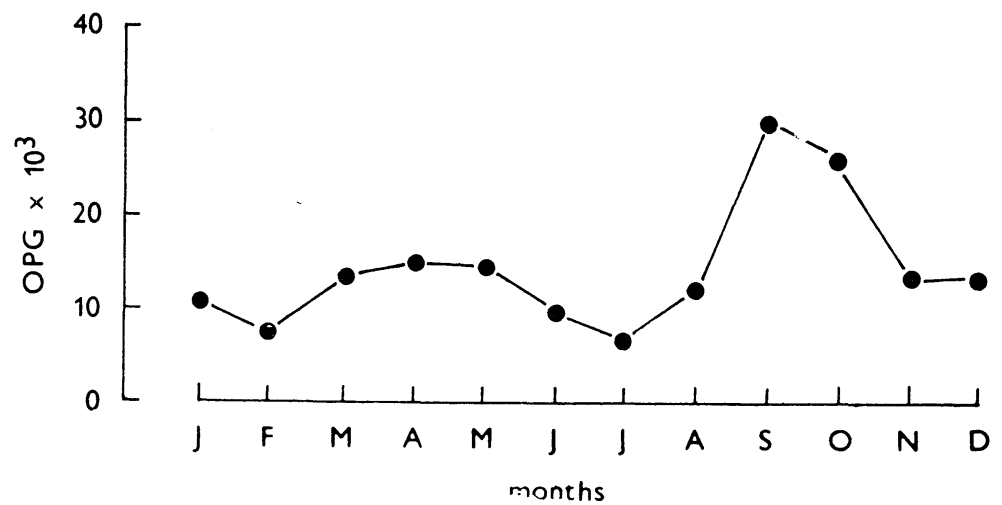

Fig. 2. Coccidial infestation curve of free living hares based on faecal examinations of samples collected in natural habitats during the year.

Table 3

Distribution of coccidial species in hare faecal samples

\begin{tabular}{|l|c|c|c|c|c|c|c|}
\hline \multirow{2}{*}{ Samples collected } & \multicolumn{6}{|c|}{ Distribution of coccidial species - per cent } \\
\cline { 2 - 8 } & $\begin{array}{c}\text { E. } \\
\text { leporis }\end{array}$ & $\begin{array}{c}\text { E. } \\
\text { robertsoni }\end{array}$ & $\begin{array}{c}\text { E. } \\
\text { europaea }\end{array}$ & $\begin{array}{c}\text { E. } \\
\text { hungarica }\end{array}$ & $\begin{array}{c}\text { E. } \\
\text { semisculp. }\end{array}$ & $\begin{array}{c}\text { E. } \\
\text { septentrion. }\end{array}$ & $\begin{array}{c}\text { E. } \\
\text { townsendi }\end{array}$ \\
\hline $\begin{array}{l}\text { From decayed wild } \\
\text { hares }\end{array}$ & 41.7 & 34.8 & 10 & 5.6 & 3.4 & 1.5 \\
$\begin{array}{l}\text { From natural hare } \\
\text { habitats }\end{array}$ & 37.4 & 28 & 9.4 & 5.6 & 8.3 & 9 & 2.3 \\
$\begin{array}{l}\text { From cagereared } \\
\text { hares }\end{array}$ & 47.1 & 24.8 & 8.1 & 5 & 5.5 & 6.5 & 3 \\
\hline
\end{tabular}


ving hares, and from late summer through autumn (August to October) in the cagereared animals. There was a slight increase of the oocyst excretion in all groups of hares during March, April and May. Minimum findings were obtained in the summer months of June and July in all groups of animals.

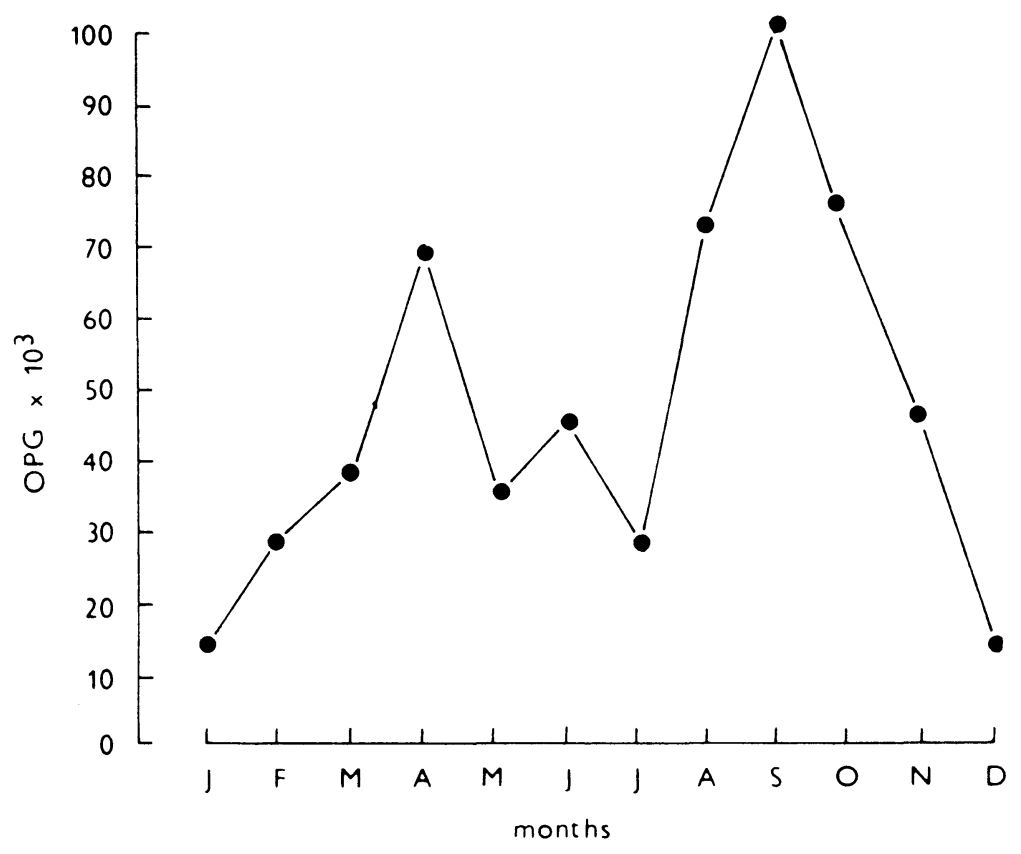

Fig. 3. Coccidial infestation curve in cage-reared hares during the year.

The coccidia species isolated and identified are given in Table 3. In all cases of infestation two species dominated: $E$. leporis and $E$. robertsoni together comprising $65-76 \%$ of all excreted oocysts in the course of the year (E. leporis $37.4-47.1 \%$, E. robertsoni $24.8-34.8 \%$ ). Other species were found in considerably lower numbers, e.g. E. europaea $8.1-10 \%$, E. hungarica 5.0-5.6\%, E. semisculpta 3.6-8.3\%, E. septentrionalis $3.4-9 \%$ and $E$. townsendi $1.5-3 \%$.

\section{Discussion}

Our study of infestation dynamics in wild hares was carried out for 6 years and in the cage-reared animals for 3 years. As shown in Tables 1 and 2, the collection of samples throughout the year was fairly regular, thus allowing for summation and conclusions about the pattern of oocyst excretion and coccidial species distribution during the entire period of study. The lowest coccidial burden was recorded in wild hares whereas considerably higher average numbers of oocysts were shed by those animals in which coccidiosis had been diagnosed as the principal cause of death. These findings are in good agreement with the data of Štěrba (1982, 1983) and Kučera (1979). The highest average numbers of excreted oocysts during the year were found in cage-reared hares. This finding can be explained by the fact that in samples collected from the individual cages the faeces of conside- 
rably more young animals were present; in these usually much higher oocyst numbers are found.

No satisfactory explanation of infestation dynamics in hares can be presented. Should the considerable irregularity in oocyst shedding throughout the year be only observed in wild hares they could in part be explained by food availability and climatic factors. A study of forage ecology of the European hare (Homolka 1982) has shown that food availability sharply declines in the latter part of summer when the majority of plants stop growing. This could affect the course of coccidiosis, especially if climatic factors are considered (e.g. warm weather and high humidity in the spring and a further increase in humidity in the late summer and autumn). According to the data of Brüll (1979), an important factor controlling the hare population during the late summer and autumn months also in the GFR is coccidiosis particularly in the young. The author suggested that high relative humidity typical of this season could be a causative factor.

Nevertheless, these factors should be of less importance in cage-reared hares, animals in which the faecal examinations revealed much higher coccidial burden and a greater slope to the infection dynamics curve (Fig. 3).

Explanation of our findings based upon climatic factors alone seems unsatisfactory; likewise, food availability does not change during the year (except for the green forage feeding period). Further studies along this line are required.

Concerning the distribution of the coccidial species in our study no differences were detected between free living and cage-reared hares. The major species observed were $E$. leporis and $E$. robertsoni, representing more than two thirds of all oocysts shed. These findings are in agreement with our previous report (Chroust 1978) describing a total of 8 coccidial species with maximum extensity and intensity for $E$. leporis and $E$. robertsoni as well. Similar findings have also been reported by Kutzer and Frey (1976) for Austria.

\section{Dynamika invaze kokcidiemi u zajíců $v$ přírodě a $\mathrm{v}$ umělém chovu}

V průběhu r. 1977 až 1982 bylo prováděno vyšetřování na kokcídie u zajíců $z$ volné př́irody a v r. 1980-1982 u zajíců $z$ umělého chovu. Celkem bylo vyšetřeno 364 vzorků odebraných od uhynulých zajíců, 629 vzorků volně sebraných v přirozených podmínkách výskytu zajíců a 1301 vzorků odebraných od zajícủ v klecovém odchovu. Vyšetření trusu bylo prováděno jednak kvantitativně, tj. stanovením průměrného počtu vylučovaných oocyst kokcidií (OPG) a dále bylo sledováno zastoupení jednotlivých druhù kokcidií na invazích.

Výsledky ukázaly, že vylučování oocyst kokcidií má v průběhu roku dynamický charakter s maximem $\mathrm{v}$ pozdních letních a časných podzimních měsících (srpen až říjen) a další, nižší maximum na jaře (březen a duben). Minimální nálezy byly zjištovány $\mathrm{v}$ létě (červen a červenec). Křivka dynamiky vylučování kokcidií má obdobný průběh jak u zajíců $\mathrm{z}$ přírody, tak i u zajíců $\mathrm{z}$ umělého chovu. Vyšší průměrné hodnoty OPG však byly zjištovány u zajíců $\mathrm{v}$ umělém chovu.

Výsledky sledování zastoupení jednotlivých druhů kokcidií ukázaly, že na invazích se podíli hlavně dva druhy, $E$. leporis a $E$. robertsoni, které tvořily $65-76 \%$ všech vylučovaných oocyst. Další druhy kokcidií v poměru kvantitativních hodnot byly: E. europaea, E. hungarica, E. semisculpta, E. septentrionalis a $E$. townsendi. Dynamika vylučování $u$ jednotlivých druhủ kokcidií se $v$ průběhu roku nijak podstatně neměnila. 
Výsledky maji praktický význam $\mathrm{v}$ možnosti aplikace účinných kokcidiostatik v období maximálního ohrožení zajíců kokcidiózou v umělých chovech a lze je využít i u zajíců ve volnosti.

\section{Динамика инвазии кокцидиями у зайцев в природных условиях и в искусственном разведении}

В 1977-1982 гг. проводились исследования кокцидий у проживающих в естественных условиях зайцев и в 1980-1982 годах - у зайцев в искусственном разведении. В итоге было иследовано 364 о5разца, ото5ранных у павших зайцев, 629 образцов, произвольно собранных в естественных условиях жизни зайцев, и 1031 образец, отобранный у зайцев в клегочном разведении. Проводились количественные исследования кала, слдеовательно, определением средней численности выделяемых ооцистов кокцидий (ОРГ), далее изучилось представительство отдельных видов кокцидий в инвазиях.

Результаты показали, чї выделение ооцистов кокцидий в течение года огличаегся динамическим характером с максимумом в поздний легний и ранний осенний периоды (август-октябрь) и последующий, нижний максимум, всгречается весной (август и апрель). Минимальные данные были установлены летом (июнь и июль). Кривая динамики выделения кокцидий похожа у зайцев в естественных условиях на кривую зайцев искусственного разведения. Более высокие сүедние величины ОРГ были усгановлены у зайцев искусственного разведения.

Результаты исследования представительства огдельных видов кокцидий показали, что в инвазиях принимают участие главным образом два вида, E. leporis и E. robertsoni, составляющие $65-76 \%$ всех выделяемых ооцистов. Другие виды кокцидий в отношении количественных величин встречались в следующем порядке: $\quad$ E. europaea, E. hungarica, E. semisculpta, E. septentrionalis и E. townsendi. Динамика выделения у отдельных видов кокцидий в течение года существенно нисколько не менялась.

Результаты играют существенную практическую роль в возможности применения эффекгивных кокцидиосгатиков в период угрозы максимального заболевания зайцев кокцидиозом в искусственном разведении, которые можно использовать также у зайцев в сво5одной природе.

\section{References}

BARTH, D. - BRÜLL, U.: Magen-Darmhelminthen und Kokzidien beim Feldhasen (Lepus europaeus Pallas) und ihre Bekämpfung mit Thibenzole und Theracanzan. Zeitschr. Jagdwiss., 21, 1975: 15-34.

BRƯLL, U.: Medikamente für Hasen. Die Pirsch, 25, 1972: 642-645.

BRƯLL, U.: Hat der Feldhase bei uns noch gute Chancen? Jäger, 8, 1979: 22-30.

GRÄFNER, G. - GRAUBMANN, H. D. - BENDA, A.: Die Verbreitung und Bedeutung der Hasenkokzidiose in Bezirk Schwerin. Mh. Vet.-Med., 22, 1967: 449.

HAUPT, W. - HARTUNG, J.: Endoparasitenbefall der Hasen aus der Umgebung von Leipzig. Mh. Vet.-Med., 32, 1977: 339-341.

CHROUST, K.: Kvantitativní metodika pro stanovení počtu vajíček gastroenterohelmintů (oocyst kokcidii) $\mathrm{v}$ trusu přežvýkavců a koní. Laboratorní metodiky, ÚSVÚ Praha, II. Helmintózy, 1970: $16-18$.

CHROUST, K.: K determinaci a druhovému zastoupení kokcidii u zajícủ. Veterinářství, 29, 1979: 507-509. 
KUČ̌ERA, O.: Využijme zahraničních poznatků v chovu zajíců. Myslivost, 10, 1979: 222.

KUČERA, O.: Poznatky z chovu zajíců u LZ Litovel. Myslivost, 1, 1983: 14-15.

KUTZER, E.: Parasitenbefall bei Feldhasen. Wild u. Hund, 18, 1976: 833-834.

KUTZER, E. - FREY, H.: Die Parasiten der Feldhasen (Lepus europaeus) in Österreich. Berl. Münch. Tierärztl. Wschr., 89, 1976: 480-483.

NOVÁK, J. - DYK, V. - ZAVADIL, R.: Die Herbstparasitenfauna der Hasenverdaungsorgane in Südmähren und der Südslowakei. Sborník VŠZ, řada B., Brno, 14, 1966: 48-58.

PASTUSZKO, J.: The occurrence of Eimerinae, Wenyon in the hare in Poland. Acta parasit. Polon., 9, 1961: 23-26.

PELLÉRDY, L.: On the status of the Eimeria species of Lepus europaeus and related species. Acta vet. hung., 6, 1956; 452.

STARKE, R.: Eimeria - Arten des Hasen (Lepus europaeus) am linken Niederrhein. Inaug. Diss., Hannover, 1976: 1-54.

ŠTĚRBA, F.: Hlavní příčiny ztrát zaječí zvěře v letech 1975-1979. Folia venatoria, 12, 1982: $239-259$.

ŠTĚRBA, F.: Rozbor přičin ztrát zajíců. Myslivost, 7, 1983: 150-151. 